Our Nature (2009) 7:177-181

\title{
Ecophysiology of Mimosa pudica L. at Biratnagar, Eastern Nepal
}

\author{
B. Niroula, D. Parajuli and S. Jha \\ Department of Botany, Post Graduate Campus, Tribhuvan University, Biratnagar, Nepal
}

Received: 13.11.2008, Accepted: 18.08.2009

\begin{abstract}
All the freshly collected mature seeds of $M$. pudica were greenish in colour, whereas 7 year old stored seeds were a mixture of greenish and brownish seeds. The greenish seeds had hard seed coat and acid treated as well as sand rubbing for 6-10 min greatly enhanced their germination percentage. The brownish seeds were simply the deteriorated form of greenish seeds. Leaves and pods had higher contribution to total plant dry weight in ungrazed field and in pot-cultured plants clipped a month before flowering. The young shoots of the plant had $18.9 \%$ crude protein, $0.46 \%$ phosphorus and $25.4 \%$ crude fibre on dry weight basis.
\end{abstract}

Key words: Hard seed coat, Mimosa pudica, scarification, dry matter production

\section{Introduction}

Known as "Lajabati" in Nepal, "Chhui-mui" in north India, "Sensitive plant" in Australia, "Sien-sien" in Suriname, and "Hila-hila" in Hawaii, Mimosa pudica L. is a pantropical forage legume (native of tropical America), commonly found in waste ground in association with Imperata cylindrica, Cynodon dactylon, Rungia pectinata and other herbaceous species in the Terai lowland of Nepal. It is a diffuse undershrub, 50 to $90 \mathrm{~cm}$ high with stem and rachis clothed with broad-based, blacktipped recurved prickles. Leaves are small, bipinnate and extremely sensitive to touch; pinnae are $2-4$, digitatively arranged, with 10 to 20 pairs of leaflets; and petioles are up to $4 \mathrm{~cm}$ long. The plant bears axillary spike inflorescence with sessile flowers arranged in pinkish globose heads. Pods are strawcoloured, bristled, and arranged in dense clusters; these are 10 to $15 \mathrm{~mm}$ long and 4 $\mathrm{mm}$ wide, flat, segmented, and somewhat constricted between the articulations; and 3 to 5 seeded (one-seeded segments). Tender plant is readily eaten by cattle. It stands heavy grazing and is reported to produce firm flesh and increased flow of milk when fed to cattle (CSIR, 1998). Being a suitable species for the restoration of the overgrazed/degraded pastures, this study pertains to seed characteristics and germination behaviour, nutrient status, and impacts of grazing (in fields) and clipping (in pot cultures) on dry matter production and partitioning into different parts (roots, stems, leaves, and fruits) of M. pudica population occurring within the premises of Post Graduate Campus, Tribhuvan University, Biratnagar, Nepal. Soil of Biratnagar (latitude $26^{\circ} 20^{\prime} \mathrm{N}$, longitude $87^{\circ} 16^{\prime} \mathrm{E}$, altitude $72 \mathrm{~m} \mathrm{msl}$ ) is made up of materials transported and deposited in relatively recent times by the tributaries of Ganga; and the climate is tropical and monsoonic with three distinct seasons: summer (March to mid-June), monsoon (mid-June to October), and winter (November to February). Average annual 


\section{B. Niroula, D. Parajuli and S. Jha / Our Nature (2009) 7: 177-181}

rainfall is $1300 \mathrm{~mm}$ out of which $80 \%$ rain is received during the monsoon season and average minimum and maximum temperatures 19 and $30^{\circ} \mathrm{C}$, respectively. Relative humidity is highest $(87 \%)$ in the monsoon season and lowest (69\%) during the summer season.

\section{Materials and methods}

$M$. pudica seeds were collected in February, 1998 (old seeds) as well as in February, 2005 (fresh seeds) from the grazing field of Post Graduate Campus. They were dried in shade for 7-8 days and stored in hermetically sealed pouches under ordinary storage condition at room temperature for the study of their physical attributes and germination behaviour. Germination studies were performed between April-May, 2005 in petridishes $(4.5 \mathrm{~cm}$ diam) on filter paper saturated with distilled water. Moisture was maintained by daily monitoring, with distilled water added as needed, and germination was defined as radicle emergence. All sets of treatments and control contained four replicates, each of 20 seeds. Seeds were inspected everyday until germination become static. Further, since both fresh and old seeds responded poorly to soaking in water alone for germination, they were treated with concentrated sulphuric acid for 2-10 min to enhance germination.

Dry matter production and partitioning in $M$. pudica was studied both in field and in pot- culture. Twenty individuals from heavily grazed and 20 individuals from ungrazed portions of the grazing field of P.G. Campus were excavated on the random basis in first week of December, 2005. The soil was washed off, the roots and plants were separated into root, stem, leaf, and pod fractions, and each fraction was dried to a constant weight at $80^{\circ} \mathrm{C}$ and weighed. For the pot-culture experiments, $M$. pudica seeds collected in February, 2005 were sown in third week of May, 2005 in earthen pots $(25 \mathrm{~cm}$ diam $)$ filled with garden soil and kept at the open terrace of the science building of P.G. Campus. The pots were watered daily until the cultured plants were $10 \mathrm{~cm}$ high (first week of July, 2005). Thereafter plants were thinned to only one individual/pot. Five sets of such pots (each set of three pots) were maintained under different conditions as: (a) unclipped individuals, (b) individuals clipped once at 5 $\mathrm{cm}$ height from the pot surface on July, 25, i.e., 15 days after thinning (dat); August, 9 (i.e., 30 dat); August, 25 (i.e., 45 dat); and September, 10 (i.e., 60 dat), respectively. All such pot sets were irrigated at every 3-4 days intervals till the third week of November. The plants were taken out of the pots for determination of dry weight production and partitioning on 10 December, 2005.

Young shoots of $M$. pudica collected from heavily grazed field in the first week of September were analysed for crude protein by micro-Kjeldal method, crude fibre by soxhlet extraction method, phosphorus by chlorostannous-reduced molybdophosphoric blue colour method, and total ash by muffle furnace (silica dishes) method.

\section{Results and discussion}

Although a mixture of greenish $(\mathrm{Gr})$ and brownish $(\mathrm{Br})$ seeds were found in nearly equal proportion in 7 year old stored seeds; all the freshly collected seeds were greenish (Gr) in colour. Fresh and old Gr seeds were similar in length, breadth, thickness and viability, but the old $\mathrm{Br}$ seeds, although similar to old Gr seeds in weight, had least 
B. Niroula, D. Parajuli and S. Jha / Our Nature (2009) 7: 177-181

(only $12 \%$ ) viability (Table 1).Germination was very low in the unscarified seeds but acid scarification for 6-10 min enhanced germination up to $100 \%$ in both fresh and old Gr seeds (Table 2). Rubbing with sand for 6 min caused $100 \%$ germination in fresh Gr seeds but old Gr seeds required longer duration $(10 \mathrm{~min})$ of sand rubbing for a better percentage of germination (Table 3). Acid treatment as well as sand rubbing failed to enhance percentage germination in old $\mathrm{Br}$ seeds. It may thus be inferred that both fresh and old Gr seeds had hard seed coat. The hard seed coat has several advantages, in that, it allows endozoic dispersal, recolonization after fire, and helps the seeds to withstand unfavourable conditions such as heat, draught, digestive juice as well as mechanical damage (Tybirk, 1991). Jha and Jha (2006) have reported that presence of yellowish-brown (with hard seed coat) and brick-red (without hard seed coat) seeds in the freshly collected mature pods of the forage legume Alysicarpus vaginalis, former for the seed bank and future germination and the latter for immediate germination. This study indicates that brownish seeds of $M$. podia were simply the deteriorated and/or nonviable seeds.

Total dry weight (TDW) of six month old $M$. pudica plant was 20.1 and $4.8 \mathrm{~g}$, respectively in protected and heavily grazed field (Table 4). In pot-culture also unclipped individuals had more TDW than the clipped ones. Contribution of root to TDW was higher in heavily grazed field (57.2\%) and in pot- cultured plants clipped after 60 days of thinning $(25.8 \%)$; that of stem in ungrazed field $(57.9 \%)$ and in pot-cultured plants clipped after 15 days of thinning (58.5\%). Leaves and pods had higher contribution to TDW in ungrazed field, and in plants clipped after 45 days of thinning. In general, green and leafy materials are preferred for animal performance because they contain more nitrogen, soluble carbohydrates and phosphate and less fibre than the older materials (Nelson and Moser, 1994; Shankar and Singh, 1996). Besides, defoliation is essential to keep $M$. pudica plants in order as they become more and pricklier with age.

The value of any feed depends on the quantity eaten and the extent to which the food consumed supplies the animal with energy, protein, minerals and vitamins. The crude protein percentages reported for tropical legumes vary from 5.6 for Stylosanthes humilis (Newman, 1968) to 35.8 for the leafier parts of Leucaena leucocephala (Hutton and Bonner, 1960), with a mean crude protein percentage of $17.2 \%$ for all legumes (Skerman et al., 1988). The crude fibre percentage of tropical legumes vary from 12.4 for Leucaena leuccephala (Farinas, 1951) to 43.4 for Macroptilium lathyroides (Milford, 1967), with a mean value of $30.6 \%$ (Skerman et al., 1988). The phosphorus contents of tropical legumes vary from $0.06 \%$ in Stylosanthes humilis (Fisher, $1969)$ to $0.65 \%$ in Pueraria phaseoloides (Blasco and Bohorquez, 1968). It is to be noted that the young shoots of $M$. pudica in September, 2005 had $18.9 \%$ crude protein, $25.4 \%$ crude fibre, $0.46 \%$ phosphorus, $7.18 \%$ total ash and $92.82 \%$ organic mattera good nutritive value for any forage legume.

\section{Acknowledgements}

Authors are thankful to Head, Department of Botany, Post Graduate Campus, Tribhuvan University, Biratnagar for facilities. Thanks are also due to National 
B. Niroula, D. Parajuli and S. Jha / Our Nature (2009) 7: 177-181

Table 1. Physical attributes of fresh and 7- years old $M$. pudica seeds.

\begin{tabular}{|c|c|c|c|c|c|c|c|c|c|}
\hline SN & $\begin{array}{l}\text { Seed } \\
\text { age }\end{array}$ & Colour & $\begin{array}{l}\text { Length } \\
\text { (l) (mm) }\end{array}$ & $\begin{array}{l}\text { Breadth } \\
\text { (b) } \\
(\mathrm{mm})\end{array}$ & $\begin{array}{l}\text { Thickne } \\
\text { ss (mm) }\end{array}$ & $\begin{array}{l}\text { Size } \\
\text { index } \\
(1 / b)\end{array}$ & $\begin{array}{l}\text { Shape } \\
\text { index }(\mathbf{l} \times \mathbf{b})\end{array}$ & $\begin{array}{l}\text { Weigh } \\
\text { t (mg) }\end{array}$ & $\begin{array}{c}\text { Viability } \\
(\%)\end{array}$ \\
\hline \multirow{2}{*}{1} & \multirow{2}{*}{ Old } & Brownish & 2.9 & 2.5 & 1.3 & 1.16 & 7.25 & 6.01 & 12 \\
\hline & & Greenish & 2.7 & 2.5 & 1.3 & 1.08 & 6.75 & 6.01 & 100 \\
\hline 2 & Fresh & Greenish & 2.7 & 2.4 & 1.3 & 1.12 & 6.48 & 5.07 & 100 \\
\hline
\end{tabular}

Table 2. Germination responses of fresh and 7-years old $M$. pudica seeds to acid Scarification for various durations.

\begin{tabular}{|c|c|c|c|c|}
\hline \multirow{3}{*}{ SN } & \multirow{3}{*}{ Duration (min) } & \multicolumn{3}{|c|}{$\%$ Germination } \\
\hline & & \multirow{2}{*}{ Fresh } & \multicolumn{2}{|c|}{ Old } \\
\hline & & & Greenish & Brownish \\
\hline 1 & 0 & 10 & 10 & 12 \\
\hline 2 & 2 & 60 & 31 & 12 \\
\hline 3 & 4 & 83 & 71 & 6 \\
\hline 4 & 6 & 100 & 100 & - \\
\hline 5 & 8 & 100 & 100 & - \\
\hline 6 & 10 & 100 & 100 & - \\
\hline 7 & 15 & 100 & 73 & - \\
\hline 8 & 20 & 36 & 13 & - \\
\hline
\end{tabular}

Table 3. Germination responses of fresh and 7- year old $M$. pudica seeds to Sand rubbing for various duration.

\begin{tabular}{ccccc}
\hline & \multirow{3}{*}{ SN } & Duration (min) & Fresh & G Germination \\
\cline { 3 - 5 } & & & Greenish & Old \\
\hline 1 & 0 & 10 & 10 & 12 \\
2 & 2 & 60 & 8 & 12 \\
3 & 4 & 83 & 46 & 6 \\
4 & 6 & 100 & 46 & - \\
5 & 8 & 100 & 83 & - \\
6 & 10 & 100 & 25 & - \\
7 & 15 & 38 & & - \\
\hline
\end{tabular}

Table 4. Resource allocation pattern in six months old plants in root, stem, leaves and fruits (mean \pm SE) under different conditions. Figures in parenthes is indicate the percentage contribution of the concerned parts to total dry weight.

\begin{tabular}{|c|c|c|c|c|c|c|}
\hline \multirow{2}{*}{$\begin{array}{l}\text { Treatments } \\
\text { (Conditions) }\end{array}$} & \multicolumn{5}{|c|}{ Dry weight (g) } & \multirow{2}{*}{$\begin{array}{l}\text { Root/ } \\
\text { shoot }\end{array}$} \\
\hline & $\overline{\text { Root }}$ & Stem & Leaves & Fruits & Total & \\
\hline Protected field & $\begin{array}{c}3.54 \pm 0.33 \\
(17.6)\end{array}$ & $\begin{array}{c}11.66 \pm 0.84 \\
(57.9)\end{array}$ & $\begin{array}{c}2.60 \pm 0.24 \\
(13.2)\end{array}$ & $\begin{array}{c}2.3 \pm 0.12 \\
(11.4)\end{array}$ & $20.1 \pm 2.01$ & 0.21 \\
\hline $\begin{array}{l}\text { Heavily grazed } \\
\text { field }\end{array}$ & $\begin{array}{c}2.74 \pm 0.18 \\
(57.2)\end{array}$ & $\begin{array}{c}1.52 \pm 0.17 \\
(31.8)\end{array}$ & $\begin{array}{c}0.4 \pm 0.03 \\
(8.4)\end{array}$ & $\begin{array}{c}0.14 \pm 0.01 \\
(2.6)\end{array}$ & $4.8 \pm 0.40$ & 1.3 \\
\hline $\begin{array}{l}\text { Clipping after } 15 \\
\text { days of thinning }\end{array}$ & $\begin{array}{c}2.44 \pm 0.24 \\
(17.8)\end{array}$ & $\begin{array}{c}7.92 \pm 0.16 \\
(58.5)\end{array}$ & $\begin{array}{c}1.8 \pm 0.10 \\
(13.3)\end{array}$ & $\begin{array}{c}1.42 \pm 0.11 \\
(10.4)\end{array}$ & $13.5 \pm 0.34$ & 0.21 \\
\hline $\begin{array}{l}\text { Clipping after } 30 \\
\text { days of thinning }\end{array}$ & $\begin{array}{c}1.4 \pm 0.09 \\
(13.7)\end{array}$ & $\begin{array}{c}5.8 \pm 0.28 \\
(56.9)\end{array}$ & $\begin{array}{c}2.1 \pm 0.12 \\
(20.6)\end{array}$ & $\begin{array}{c}0.9 \pm 0.08) \\
(8.8)\end{array}$ & $10.2 \pm 0.33$ & 0.15 \\
\hline $\begin{array}{l}\text { Clipping after } 45 \\
\text { days of thinning }\end{array}$ & $1.4 \pm 0.09$ & $2.78 \pm 0.31$ & $3.32 \pm 0.07$ & $1.14 \pm 0.17$ & $8.64 \pm 0.48$ & 0.19 \\
\hline
\end{tabular}


B. Niroula, D. Parajuli and S. Jha / Our Nature (2009) 7: 177-181

\begin{tabular}{|c|c|c|c|c|c|c|}
\hline & (16.2) & (32.2) & (38.4) & (13.2) & & \\
\hline $\begin{array}{l}\text { Clipping after } 60 \\
\text { days of thinning }\end{array}$ & $\begin{array}{c}1.92 \pm 0.16 \\
(25.8)\end{array}$ & $\begin{array}{c}3.52 \pm 0.12 \\
(47.2)\end{array}$ & $\begin{array}{c}1.4 \pm 0.09 \\
(18.7)\end{array}$ & $\begin{array}{c}0.62 \pm 0.12 \\
(8.3)\end{array}$ & $7.46 \pm 0.22$ & 0.35 \\
\hline Unclipped & $\begin{array}{c}2.06 \pm 0.32 \\
(14.2)\end{array}$ & $\begin{array}{c}8.2 \pm 0.29 \\
(56.7)\end{array}$ & $\begin{array}{c}2.9 \pm 0.18 \\
(20.1)\end{array}$ & $\begin{array}{c}1.3 \pm 0.11 \\
(9.0)\end{array}$ & $14.6 \pm 0.27$ & 0.16 \\
\hline
\end{tabular}

Agriculture Research Council (NARC), Khumaltar for nutrient analyses.

\section{References}

Blasco, L.M. and A.N. Bohorquez 1968. Pasture species in the Amazon region (of Colombia). I. Analysis of some chemical components. Agric. Trop. 24: 175-177.

CSIR (Council of Scientific and Industrial Research) 1998. The wealth of India : Raw materials. Vol. VI. CSIR, New Delhi.

Farinas, E C. 1951. Ipil- ipil, the "alfalfa" of the tropics: Its establishment, culture and utilizations as a fodder and pasture crop. Philipp. J. Anim. Ind. 12: 65-68.

Fisher, M.J. 1969. The growth and development of Townsville Lucerne (Stylosanthes humilis) in ungrazed swards at Katherine, Northern Territory. Aus. J. Expt. Agric. Anim. Husb. 9: 196-208.

Hutton, E.M. and I. Bonner 1960. Dry matter and protein yields of four strains of Leucaena glauca Benth. J. Aus. Inst. Agric. Sci. 26: 276-277.

Jha, S. and P.K. Jha 2006. Germination responses of some forage species of eastern Terai, Nepal. Ecoprint 13: 49-60.

Milford, R. 1967. Nutritive values and chemical composition of seven tropical legumes and Lucerne grown in subtropical south eastern Queensland. Aus. J. Exp. Agric. Anim. Husb. 7: 540-5345.

Nelson, C.J. and L.E. Moser 1994. Plant factors affecting forage quality. In Forage Quality, Evaluation and Utilization (Eds. G.C. Fahey, Jr. ASA, CSSA and SSSA Medison), USA. pp. 115154.

Newman, D.M.R. 1968. A comparison of nutritional value of Stylosanthes humilis, Stylosanthes guyanensis and introduced grasses in northern Australia. Aust. J. Expt. Agric. Anim. Husb. 8: 172176.

Shankar, V. and J.P. Singh 1996. Grazing ecology. Trop. Ecol. 37 (1): 67-78.

Skerman, P.J., D.G. Cameron and F. Riveros 1988. Tropical forage legumes. Food and Agriculture Organization of the United Nations, Rome.

Tybirk, K. 1991. Regeneration of woody legumes in Sahel. AAU Report 27, Aarhus University Press, Aarhus. 